\title{
Thoughts on Kinship at the Citizenship Office in South Sudan
}

\author{
Ferenc Dávid Markó \\ Central European University, Budapest
}

\begin{abstract}
Building of a yearlong anthropological fieldwork inside the South Sudanese citizenship office, the paper elaborates the topic of the negotiated statehood through an analysis of the flexibility of kinship. As almost nobody in South Sudan posses genuine birth certificates, the new country struggles to verify the citizenship-applicants, and recognise the fraudulent applications. South Sudan introduced an ethnicity and kinship-based system. Each and every applicant has to arrive with a 'next of kin', an elder, blood-relative, to verify her life-story. These debates between verification officers and applicants open up a new space for kinship studies. The paper concludes, that nevertheless the continued flexibility of the meaning of kinship these situations cannot be understood without the normative basis of kinship.
\end{abstract}

Keywords: Anthropology of the state, Kinship, South Sudan, East Africa, Civil war, State, Bureaucracy

"The average anthropologist (...) has his doubts whether the effort needed to master the bastard algebra of kinship is really worth while. He feels, that, after all, kinship is a matter of flesh and blood, the result of sexual passion and maternal affection, of long intimate daily life, and of a host of personal intimate interest. Can all this really be reduced to formulas, symbols, perhaps equations?(...) The average common-sense anthropologist or observer of savages feels that this personal approach to kinship is sadly lacking. There is a vast gulf between the pseudo-mathematical treatment of the too-learned anthropologist and the real facts of savage life. Nor is this merely the feeling of the non-specialist. I must frankly confess that there is not a single account of kinship in which I do not find myself puzzled by some of this spuriously scientific and stilted mathematization of kinship facts. (...) I believe that kinship is really the most difficult subject of social anthropology; I believe that it has been approached in a fundamentally wrong way." (Bronisław Malinowski, 1930) 
I spent my year-long fieldwork in South Sudan at the Directorate of Nationality, Passport and Immigration (hereinafter: DNPI), which falls under the authority of the new country's police force. ${ }^{1}$ I just observed a citizenship interview where the Dinka officer did not accept as a witness the relative - a maternal cousin - of a Kakwa applicant, arguing that the law requires a paternal, older relative. The two sides got into a long dispute about who qualifies as a relative and who does not. The Dinka police officer insisted that he can only accept a witness who has at least one name of the four that is the same as the applicant's, meaning that according to the Dinka (as well as Nuer and Shilluk) naming system, they have at least one grandfather in common. By the end of the debate, the applicant managed to convince the bureaucrat that although the Kakwa are also a patrilineal ethnic group, ${ }^{2}$ maternal uncles - and, accordingly, their children play a more important role in family life than the father, while on the other hand, due to the logic of the Kakwa naming system, kinship would not be clear even in the case of paternal relatives. After some hesitation, the Dinka police officer accepted the applicant's arguments and was willing to interrogate the witness.

All of a sudden I found myself in the middle of the anthropological debates of the last century. Of course my fieldwork location was not chosen by accident. I was attracted by the intimate relationship between the discipline of anthropology and South Sudan, from the divine kingship of the Shilluk that had such a central role in James Frazer's The Golden Bough (Frazer 1913; Evans-Pritchard [1948] 2011; Graeber 2011), through the relativism of Azande witchcraft (EvANS-PRITCHARD 1937) ${ }^{3}$ and the premise of stateless societies derived from the lineage-based political system of the Nuer (FoRTES - Evans-Pritchard 1940; Evans-Pritchard 1940; Hutchinson 1996), all the way to Godfrey Lienhardt's study of Dinka religion (LiEnHARDT 1961; CoRMaCK 2014). ${ }^{4}$ Despite all this, I did not plan on dealing with the topic of kinship directly. My research focused on the institutionalization of South Sudanese citizenship. I was most interested in finding out how a newly created - and relatively weak - state can select and document its own citizens, provided that the majority of the applicants have neither a birth certificate nor a previous, Sudanese identity card. The first six months of my fieldwork

\footnotetext{
${ }^{1}$ My fieldwork was made possible by a research grant from the Wenner-Gren Foundation for Anthropological Research and an academic scholarship from Central European University. Archival work was conducted at Oxford and Durham Universities. I am grateful for all the support. This article is a slightly revised version of an earlier piece written in Hungarian (MARKó 2014).

I left South Sudan in November 2013, a few weeks before the outbreak of the latest civil war, which is why my article does not address the tragic period since then. In the short, peaceful year I spent there, Nuer and Dinka police officers worked together at the Citizenship Office.

${ }^{2}$ See Marisa Ensor's article about Kabili, a Kakwa child soldier (Ensor 2012).

${ }^{3}$ See also: GeERTz 1983:73-93 or Jennings' philosophical approach to "Zande common sense" (JENNINGS 1989), as well as the resulting debate about relativism (TRIPLETT 1994; SANKEY 2010).

${ }^{4}$ Godfrey Lienhardt spent 18 months among the Gogrial-area Dinka as Evans-Pritchard's student and with his support, focusing primarily on religious life. After his mentor's retirement, he succeeded him at the head of the department of anthropology at Oxford. Zoe Cormack's dissertation, based upon nearly two years of fieldwork, but also synthesizing Lienhardt's books, photographs, field notes, letters, as well as British and (South) Sudanese archival materials - which she submitted to the history department of Durham University - presents Dinka kinship, gender roles, and the way the Gogrial-area Agouk Dinka remember the past and imagine the future in this light, from a completely new aspect (CORMACK 2014).
} 
were spent at the DPNI, as well as socializing with lower ranking officials working there. In the second half of the year, I continued my research among the applicants seeking citizenship. I interviewed applicants and members of South Sudanese non-governmental organizations, and tried to map out the - mostly illegal - market of documents validating an applicant's affiliation with South Sudan that evolved in the vicinity of the office.

According to the Nationality Act approved two days before the proclamation of South Sudan, one can be considered a native of South Sudan if "such person belongs to one of the indigenous ethnic communities of South Sudan", ${ }^{5}$ however, the law did not come with a list of indigenous ethnic groups, nor a list of members of ethnic groups living on both, or in some cases all three, ${ }^{6}$ sides of the border. Thus, in the case of a dispute, the decision is entirely in the hands of the police officer conducting the hearing. The South Sudan Nationality Regulations supplementing the act require that, in addition to properly completed forms and any available evidence, "the applicant must provide a witness(es) who is/are believed to be elders and next of kin".

"Next-of-kin" is an Anglo-Saxon legal category. According to my informants, the text of the South Sudanese Nationality Act and the supplementary Regulations were codified by lawyers repatriating from the United States. However, according to the Dinka major general running the office, they were not given any kind of instruction as to how exactly they should evaluate the evidence and whom they should admit as a witness. The major general and his direct staff - mostly Dinka and Nuer - relied on "common sense" in the Geertzian meaning (GEERTz 1983:73-93) when they created the official naming system of the new state, on the one hand, and a selection mechanism, on the other hand, which best ensures compliance with the law by having close relatives of the applicant testify. The three Nilotic ethnic groups living in the northern part of South Sudan (Dinka, Nuer, Shilluk), which make up about 55-60\% of South Sudan's population, ${ }^{8}$ follow a naming system based on patrilineal descent. The newborn child's name - if a second name is not given in baptism - is generally followed by the name of the father (in exceptional cases the guardian) and the grandfather (father of the guardian), sometimes spanning six or seven generations (for a detailed description of the Dinka naming system, see DeNG 1972:38-40). ${ }^{9}$ The clarity of the system is assisted by the fact that wives do not take

\footnotetext{
${ }_{5}^{5}$ The South Sudan Nationality Act, 2011. http://www.refworld.org/docid/4e94318f2.html (accessed July 27, 2016)

${ }^{6}$ Approximately 1.1 million Azande live in the area of the Democratic Republic of Congo, Central African Republic and South Sudan triple border, often nurturing family relationships across borders. Hundreds of thousands of Eastern Nuer remain divided between Ethiopia and South Sudan (JOHNSON 2010).

${ }^{7}$ South Sudan Nationality Regulations, 2011, Chapter I, Article 25. http://www.refworld.org/ docid/4ffab4582.html (accessed July 27, 2016)

${ }^{8}$ Fifth Sudan Population and Housing Census, 2008. http://ghdx.healthdata.org/record/sudanpopulation-and-housing-census-2008 (accessed July 27, 2016)

9 A man's name is combined with his father's name as, for example, "Kwol, son of Arob, son of Biong, son of Allor" - and on to the degree necessary for identification. To state the relationship involved it may be necessary for a person to introduce his father, grandfather, and maybe the founder of his clan. Among other things, this serves as a guiding chart for the observance of exogamous bars. By knowing each other's ascendants, a couple can more or less tell whether marriage between them is permissible" (DeNG 1972:38-40). This same "incest logic" is followed, but of course in reverse, at the DNPI when comparing the applicant's and witness' names.
} 
their husband's name. The senior bureaucrats at the DPNI envisioned this system as the basis of the new government system, with the stipulation that the official name must always consist of four names, where the last name will be the "family name". ${ }^{10}$ Naturally, however, in this case only the paternal lineage shows the degree of kinship, because the names of the maternal or affinal relatives contain the paternal ancestors of the Ego. Demonstrated through a concrete example, let us assume that the Dinka Jok Deng Adout Kiir is applying for citizenship and brings a paternal cousin to testify.

\begin{tabular}{|l|l|l|l|l|}
\hline applicant & $\begin{array}{l}\text { Jok } \\
\text { (name) }\end{array}$ & $\begin{array}{l}\text { Deng } \\
\text { (father) }\end{array}$ & $\begin{array}{l}\text { Adout } \\
\text { (grandfather) }\end{array}$ & $\begin{array}{l}\text { Kiir } \\
\text { (great-grandfather) }\end{array}$ \\
witness (cousin) & $\begin{array}{l}\text { Achak } \\
\text { (name) }\end{array}$ & $\begin{array}{l}\text { Luol } \\
\text { (father) }\end{array}$ & $\begin{array}{l}\text { Adout } \\
\text { (grandfather) }\end{array}$ & $\begin{array}{l}\text { Kiir } \\
\text { (great-grandfather) }\end{array}$ \\
\hline
\end{tabular}

Figure 1. Dinka applicant, a hypothetical ideal case.

Clearly, the names of the grandfather and great-grandfather are the same name, so the official can see that they are certainly relatives, namely cousins. Of course, the situation gets complicated even among the Dinka, Nuer and Shilluk by taking on a baptismal name (usually, but not always, used after the first given name, so in our hypothetical case, our witness would be called Achak *John* Luol Adout); furthermore, in many cases men without a herd - i.e., wealth - can pay neither the bride price nor any compensation to the bride's parents, so the children get associated with the patrilineal branch of the maternal uncles, ${ }^{11}$ and they will be named accordingly. Individuals coming from such families have two options when applying for citizenship at the DNPI. Either they seek out their father and ask him or one of his relatives to testify for them, in which case, of course, their official name will be different from the name they used so far, as the name of their father, grandfather and sometimes great-grandfather will replace the name of their maternal uncle and his patrilineal ancestors; or they claim on the papers that their maternal uncle is their biological father, and then they can bring to testify any of the relatives they grew up with. The child of their uncle, for example, who is "really" a matrilineal cousin, but at the office they claim to be patrilineal siblings. Recycling the names used in the previous example, let us suppose that the Dinka Jok Deng Adout Kiir, who was born out of wedlock and raised by his maternal uncle (or his patrilineal branch) applies for citizenship. If he follows the paternal line, he must get a new name; if the maternal line, he must lie about his father, on the one hand, and about the witness' degree of kinship, on the other hand.

\footnotetext{
${ }^{10}$ Obviously, this way a father and son's family name can never be the same. The family name category was necessary due to the machines producing identity cards that were imported from Europe, as they invariably operate on the family name - first name logic.

${ }^{11}$ Evans-Pritchard writes about this in detail (EvANS-PRITCHARD 1951:26-27), and see also Hutchinson's Nuer monograph: Hutchinson 1986, McKinnon's article on the creation of Nuer patrilineality: MCKINNON 2000, and Gough's article: GougH 1971, according to whom nearly half of the children in Nuer- and Dinkaland were born in such families (and this is data from before the second civil war!).
} 


\begin{tabular}{|c|c|c|c|c|}
\hline applicant & $\begin{array}{l}\text { Jok } \\
\text { (name) }\end{array}$ & $\begin{array}{l}\text { Deng } \\
\text { (maternal } \\
\text { uncle) }\end{array}$ & $\begin{array}{l}\text { Adout } \\
\text { (maternal } \\
\text { grandfather) }\end{array}$ & $\begin{array}{l}\text { Kiir } \\
\text { (maternal great- } \\
\text { grandfather) }\end{array}$ \\
\hline applicant's official name & $\begin{array}{l}\text { Jok } \\
\text { (name) }\end{array}$ & $\begin{array}{l}\text { Achak } \\
\text { ("biological"12 } \\
\text { father) }\end{array}$ & $\begin{array}{l}\text { Luol } \\
\text { (grandfather) }\end{array}$ & $\begin{array}{l}\text { Wek } \\
\text { (great-grandfather) }\end{array}$ \\
\hline witness (paternal sibling) & $\begin{array}{l}\text { John } \\
\text { (name) }\end{array}$ & $\begin{array}{l}\text { Achak } \\
\text { ("biological" } \\
\text { father) }\end{array}$ & $\begin{array}{l}\text { Luol } \\
\text { (grandfather) }\end{array}$ & $\begin{array}{l}\text { Wek } \\
\text { (great-grandfather) }\end{array}$ \\
\hline
\end{tabular}

Figure 2. Dinka applicant raised by maternal uncle who secures a patrilineal kin witness.

\begin{tabular}{|l|l|l|l|l|}
\hline applicant & $\begin{array}{l}\text { Jok } \\
\text { (name) }\end{array}$ & $\begin{array}{l}\text { Deng } \\
\text { (maternal } \\
\text { uncle) }\end{array}$ & $\begin{array}{l}\text { Adout } \\
\text { (maternal } \\
\text { grandfather) }\end{array}$ & $\begin{array}{l}\text { Kiir } \\
\text { (maternal great- } \\
\text { grandfather) }\end{array}$ \\
applicant's official name & $\begin{array}{l}\text { Jok } \\
\text { (name) }\end{array}$ & $\begin{array}{l}\text { Deng } \\
\text { (maternal } \\
\text { uncle) }\end{array}$ & $\begin{array}{l}\text { Adout } \\
\text { (maternal } \\
\text { grandfather) }\end{array}$ & $\begin{array}{l}\text { Kiir } \\
\text { (maternal great- } \\
\text { grandfather) }\end{array}$ \\
Alex (cousin) & $\begin{array}{l}\text { Adout } \\
\text { (name) } \\
\text { (father) }\end{array}$ & $\begin{array}{l}\text { Krandfather) } \\
\text { (great-grandfather) }\end{array}$ \\
\hline
\end{tabular}

Figure 3. Dinka applicant raised by maternal uncle who secures a matrilineal kin witness.

I have seen examples for both strategies; in each case, the applicant's choice was the result of individual decision. Factors include which branch of relatives is easier to contact in Juba, which branch is easier to ask for favors, how much the applicant insists on having the "real" name appear on the identity card, and countless personal reasons. Of course, there have also been examples of someone refusing to change the name or lie about the kinship relationship. In such cases, the decision is left up to the individual official whether to recognize the applicant as South Sudanese or not. If at first sight you, my reader, find the system too complex and too difficult to follow, you can be assured that most of the applicants did not understand it either. Particularly when it came to non-Dinka, Nuer or Shilluk applicants, there were long disputes between the police officers and the applicants.

Three ethnographic incidents support this case. The first case is about Durka, whose mother is Bari, father a Dinka soldier. ${ }^{13}$ His parents never married, their relationship was limited to the period when Durka's father was stationed around Juba as a member of

\footnotetext{
${ }^{12}$ Biological is in quotation marks here because it is far from certain, of course, that we are talking about the biological father in the scientific sense.

${ }^{13}$ The interview was made in March 2013.
} 
the SPLA. ${ }^{14}$ Durka has never met her father, only inherited her family name. At barely three years of age, she was sent to Khartoum, where her maternal uncle took care of her education. She was in Switzerland when South Sudan became independent, and to her astonishment, she became displaced from one day to the next, since Sudan's embassy in Geneva refused to renew her passport. After thirty years, she traveled home to Juba for the first time - using a temporary laissez-passer - where her application for citizenship with her old passport was unsuccessful; the police officer told him that no one can become a citizen without a witness. Her astonishment increased even further when her maternal half-brother he just recently met was not accepted as a witness. The clerk told Durka that, given the circumstances, he may have accepted a maternal kin witness, but because Durka's father was Dinka, and ethnicity is inherited patrilineally, in her case he can only consider a Dinka witness. Eventually, Durka had to find her father who was, fortunately, stationed in Juba.

My second story features Albino, an Acholi man working for the World Bank, ${ }^{15}$ who, besides his high ranking civil position, is also the leader of the semi-official umbrella organization of the Acholi community in South Sudan. Albino was born in a hospital in Khartoum, so he applied for his citizenship with his birth certificate, with his paternal cousin as a witness. The official politely told him that this birth certificate was not acceptable, because Albino's name does not match the official naming system. On the one hand, he only has three names; on the other hand, it does not include the names of his paternal ancestors. Albino argued in vain that although the Nilotic Acholi are also a patrilineal ethnic group, in their naming system it is downright unacceptable for someone to be named after their own father. Finally, he had no other option but to request a document called Age Assessment Form, on which his new name had to comply with the state logic.

As a result of nearly half a century of civil war, ${ }^{16}$ family relationships disintegrated (or were never established), thus many applicants are unable to secure witnesses complying with the law - particularly youth repatriating from Uganda, Kenya, Ethiopia, and foreigners seeking citizenship. ${ }^{17}$ They have no other option than to find someone at the "bazaar of evidence" who is willing (for a fee) to get the Age Assessment Form from the National Medical Commission filled out with the appropriate name, and testify at the DNPI.

My third ethnographic case involves two of my acquaintances from the Nuba Mountains, who fled to South Sudan from the still ongoing civil war in Sudan. According to the law, they are not South Sudanese, because despite the populations around the Nuba Mountains having had supported the SPLA for decades, upon South Sudan's secession, the area remained in Sudan. These two friends had to obtain official papers in order to accept employment - and to avoid possible deportation - therefore, they developed a strategy. Although they came from two different ethnic groups, they testified for each other, since they built a whole new life story for the agency, and they even obtained

${ }^{14}$ Sudan People's Liberation Army, the main rebel organization in the civil war in South Sudan, which has functioned both as a government party and the national army since 2005 .

${ }^{15}$ The interview was made in June 2013, together with Dr. Katrin Seidel.

16 The First Sudanese Civil War, which claimed half a million fatalities, took place between 1955 and 1972, while the Second Civil War between 1983 and 2005 claimed more than 2,000,000 victims (JOHNSON 2003).

${ }^{17}$ East African youth come to Juba either to do business, or hoping to find a job with one of the relief organizations or with the UN, which - because of the quota system "helping" the locals - is greatly expedited if they can prove that they are South Sudanese, so many of them try to obtain the documents. 
"evidence" supporting it. First of all, they selected an appropriate South Sudanese ethnic group - it had to be a group with a small population whose language was not spoken at the agency, lest they be caught - and created new names and life stories for themselves, and testified as one another's brother. Since then they have been renting a cottage together in Juba, helping each other in everyday life, and most of their South Sudanese friends think they are brothers. The life story and kinship thus created by them has gained a new life.

In his Outline of a Theory of Practice, Pierre Bourdieu explains for the first time the theory of habitus and the methodology focusing on everyday practice (BOURDIEU 1977). The theory had a productive effect on various sectors of sociology and anthropology, with the only exception being kinship studies, which is especially interesting in light of Bourdieu introducing his methodology through the analysis of a Kabyle cousin-marriage (BOURDIEU 1977:30-58). One of the few researchers who have used this theory anyway was Krista E. Van Vleet, during her research on Bolivian kinship. Van Vleet studies the evolving and ever-changing "kinship" relations among the indigenous people living in the highlands of Bolivia (VAN VLEET 2003; 2008). She introduces the concept of "relatedness", which is derived from kinship but goes beyond it, and is much more flexible that kinship structures.

"I develop critical perspectives on the cultural construction of social relationships that take kinship as their core but not as their boundary. I illuminate relatedness through a double focus. An ethnographically grounded discussion of the intimacies and hierarchies of kinship and gender among Quechua speakers who live in the rural region of Sullk'ata, Bolivia, is the heart of the book. My own negotiation of relationships with Sullk'atas is a secondary but analytically significant nexus of reflection. By highlighting the everyday talk and practices of Sullk'atas, and especially the telling and retelling of stories, I show how relatedness is a mutual production among people, including the ethnographer and her informants. People interpret meanings and relationships in process." (VAN VLEET 2008:2)

Caren Freeman's book on the cross-border marriage customs of the Korean minority living in China also falls into this category (FrEEMAN 2011). Freeman shows how the Korean government, struggling with a severe demographic crisis, encourages Chinese Koreans to "discover" kinship relations on the peninsula, and how this incentive and the promise of a better life assists in the creative invention and experience of these nonexistent kinship relationships.

In my opinion, and Bourdieu's arguments notwithstanding (BouRDIEU 1977:37), these types of studies of kinship relationships - using the category of kinship intentionally permissively - that are re-evaluated based on state influence or other external factors, invented, situational, and malleable, are rare because the two spheres of kinship relations, the familial and the political, have been traditionally separated by the discipline of anthropology (Peletz 1995; SAHLIN 2013). Evans-Pritchard's study of the Nuer was published as a trilogy, thus designating what he considered to be the three main topics of anthropology: familial-domestic kinship (Kinship and Marriage among the Nuer, 1951), politico-jural institutions (The Nuer: A Description of the Modes of Livelihood and Political Institutions of a Nilotic People, 1940), and religion (Nuer Religion, 1956). As Mayer Fortes writes - with whom Evans-Pritchard co-edited African Political Systems, the saga of segmented, stateless societies: "The major advance in kinship theory since Radcliffe- 
Brown, but growing directly out of his work, has been the analytical separation of the politico-jural domain from the familial, or domestic domain within the total social universe of what have been clumsily called kinship-based social systems" (FORTES 1969:72).

In addition to using English labels instead of emic Nuer kinship categories, ${ }^{18}$ EvansPritchard's "big trick" was the separation of political and familial kinship, as many of his critics pointed out (Evans 1984; Gough 1971; Holý 1979a; 1979b; KARP - MAYNARD 1983; KUPER 1982; MCKINNON 2000; ROSALDO 1986). While many justifiably criticize Evans-Pritchard for staying silent on anything that disturbs the egalitarian, patrilineal, clear structure, or simply relegating it to the familial sphere of kinship, they usually forget to mention that Evans-Pritchard was very much aware of the complexity of Nuer reality:

"The sentiment of mar, of communion with his kin, gives a Nuer the comfort of security, the
feeling of being in a known and friendly world. I would again stress that mar is a cognatic
kinship, a set of relationships to any person through either father or mother and, among the
Nuer, embracing also close affines, and further that in this general interpersonal sense one
does not evaluate between the relationships. The maternal uncle is just as much kin as the
paternal uncle, and the mother's sister's son as the father's sister's son. They are all people one
helps when they need help and who help oneself when one needs aid. 'Jimarida', 'my kin',
are the people who are near me, irrespective of their precise category of relationship." (EvANS-
PRITCHARD 1951:156)

The system experienced at the DNPI, which at first seemed like a strictly patriarchal system that only allowed older paternal relatives to be a witness, became more complex when looking at the individual strategies of applicants, or when the personal affairs of the Dinka and Nuer officials came to the fore. Several high-ranking police officers tried to find a job for their relatives at the police station. One older Dinka colonel - who perhaps most strictly checked and enforced that the witness be a paternal relative - secured a guard position for a young protégé. Like to everyone else in the office, he told me that the boy was a close relative (using the English term "next-of-kin" as prescribed by law). After many attempts, he turned out to be a grandson of his maternal aunt, a degree of kinship that the Dinka language has no word for (DENG 1972), but he must nevertheless take care of the boy because his matrilineal aunt entrusted him with it, and he feels towards her, as well as the boy, as Evans-Pritchard's Nuer about the mar. I got another example of the situationality and flexibility of kinship when I returned to Juba after a one-week absence. An excerpt from my field journal reveals how easily someone's classification changes in certain situations:

"I board the Cairo airport bus, and in the crowd I end up next to three men. One of them is a large, round headed, bald, muscular South Sudanese, in tidy but not conspicuously expensive

\footnotetext{
${ }^{18}$ Evans-Pritchard himself admits that, for example, the word "clan" had no equivalent in Nuer (EvansPRITCHARD 1940:195). The afterlife and numerous re- and misinterpretations of Evans-Pritchard's Nuer ethnography deserve a separate study. Here I pose only one comment, namely as regards the most famous dialogue in anthropology. At the very beginning of the first Nuer book, Evans-Pritchard illustrates the difficulty of fieldwork with the following ironic dialogue, which has been included in most academic books in the same sense:
} 
clothes. Immediately I try to categorize him, my first thought being that he is a highly skilled Equatorian ${ }^{19}$ who works for an NGO or the UN rather than the government, but not in a very high position. The second one is a nervous and seemingly confused white man in his forties, in worn clothing and with a battered bag that has seen better days. Perhaps he is a Spanish or Greek venturer, I'm thinking, struck by the crisis and trying to find some kind of work in Juba, and is obviously filled with questions. The third one is a middle-aged Middle Eastern man in a light blue sport coat, Ray-Ban sunglasses, with a large Rolex on his wrist, full of confidence. I suspect that he is an Egyptian or Lebanese businessman who either operates a hotel or a restaurant for aid workers in Juba, or has partnered with the Chinese and is doing some construction. It looks like he made his fortune in Juba."

\footnotetext{
"E.-P.: Who are you?

Cuol : A man.

E.-P.: What is your name?

Cuol : Do you want to know my name?

E.-P.: Yes.

Cuol : You want to know my name?

E.-P.: Yes, you have come to visit me in my tent and I would like to know your name.

Cuol : All right. I'm Cuol. What is your name?

E.-P.: My name is Pritchard.

Cuol: What is your father's name?

E.-P.: My father's name is also Pritchard.

Cuol : No, that cannot be true. You cannot have the same name as your father.

E.-P.: It is the name of my lineage. What is the name of your lineage?

Cuol : Do you want to know the name of my lineage?

E.-P.: Yes.

Cuol : What will you do with it if I tell you? Will you take it to your country?

E.-P.: I don't want to do anything with it. I just want to know it since I am living at your camp.

Cuol: Oh well, we are Luo.

E.-P.: I did not ask you the name of your tribe. I know that. I am asking you the name of your lineage.

Cuol: Why do you want to know the name of my lineage?

E.-P.: I don't want to know it.

Cuol: Then why do you ask me for it? Give me some tobacco" (Evans-Pritchard 1940:12-13).
}

Since the English words "lineage" and "clan" have no equivalent in this sense in Nuer, therefore the text can be interpreted - and I think this is closer to reality - as the fledgling anthropologist asking Cuol so much nonsense that in his confusion he cannot help but ask for a little tobacco to relieve the tension. It is incomprehensible why after his Nuer visitor responded to the request for his name and asked his own, Evans-Pritchard gave his last name, not his first, in response, thus confusing the conversation. Had he responded with his first name and then asked Cuol about his father's name, the entire misunderstanding could have been avoided (and he would have likely retained more tobacco).

${ }^{19}$ The political self-determination of ethnic groups living in the three southern states of South Sudan (Western Equatoria, Central Equatoria, Eastern Equatoria), through which they wish to distinguish themselves from the three Nilotic groups (Dinka, Nuer, Shilluk) who have acquired key positions in the army and in state powers. It is not a linguistic or anthropological category, since the Nilotic Acholi also consider themselves Equatorians. 
Of course, half of my stereotypes proved to be wrong, which was quickly revealed as soon as they began to talk:

"The Greek man to the South Sudanese: You live in Juba? How is Juba these days?

South Sudanese: Juba is great! Full of progress and opportunity. The weather is gorgeous. I just took my children to Nairobi and we were kind of shocked how cold it is there.

Greek: I was born in Wau, ${ }^{20}$ and haven't seen Juba in thirty years. Do you know Major General Vasily? ${ }^{21}$ He's my uncle...

Lebanese: Is this the same Greek who manages the Olympus restaurant in Juba?

Greek: No, he's Dimitris, but he's my cousin, too.

Lebanese: So you were born here? You're lucky, you can apply for a South Sudanese passport.

Greek: I don't know...

South Sudanese: But if you were born here, even if to a Greek family, you are entitled!

Greek: Actually, my father is a Cypriot, my mother a Shilluk, you just can't tell looking at me.

South Sudanese: Ha! We might even be blood relatives, I'm also Chollo, ${ }^{22}$ but I've lived in Rumbek and Juba for decades.

Greek: Do you know Boba Agar? He's my uncle, my mother's brother.

South Sudanese: Yeah, he's a cousin (embraces the new relative), so we are also cousins.

Lebanese: You can get a passport, it helps a lot if you want to live here, it unlocks lots of doors and makes everything easier. He (points to the South Sudanese man) can help you. Do you want to live here?

Greek: Yes, my brother is working for the UN, I've worked for them in Khartoum before the secession, but then it became more difficult...

South Sudanese: I can witness for you as a cousin, I even know someone at the agency, it will be easier for you at the UN, too, because they have to employ South Sudanese, take my card."

Three kinship relationships were defined as cousins by the English-speaking players, even though at most one of them can be a "truly" cousin relationship. The repatriating, half Cypriot and half Shilluk man cannot be the cousin of the Greek businessman operating the Olympus restaurant, because I know from an earlier interview that the Greek businessman is a third generation Sudanese Greek, without any Cypriot ancestors or collateral relatives. And it is quite clear that in structural terms someone cannot be one's uncle's cousin's cousin, so the two Shilluk men cannot be cousins. But in this situation, and likewise at the DNPI, the exact degree of kinship relationship does not matters, but as Evans-Pritchard said: "They are all people one helps when they need help and who help oneself when one needs aid" (Evans-Pritchard 1951:156). Marshall Sahlins, in his last book on kinship, reached a similar conclusion (SAHLins 2013). According to him, kinship is not biology, not a strict structure, but the mutuality of being, persons who are truly involved in each other's existence - and nothing more. It is in this sense when

\footnotetext{
${ }^{20}$ Wau is a South Sudanese town of 150,000 , the capital of Western Bahr el Ghazal State. It is on the border of the area inhabited by the Dinka, and is very culturally diverse (Fertit, Luo, Dinka, Arabic).

${ }^{21}$ Gregory Vasili is a half Dinka, half Greek commander in the SPLA/M, the rebel army that became a government party.

${ }^{22}$ Chollo is the name the Shilluk call themselves (Howell 1941).
} 
Pinaud writes that the warlords of the SPLA in South Sudan ${ }^{23}$ are replacing the family ties torn during and after the civil war $^{24}$ with their kinship structures by assuming their soldiers' burden of bride price instead of their destitute families, thereby ensuring that the soldiers will remain their loyal followers (PINAUd 2014).

I probably would not go so far, because, although everyone who has heard of the Nuer ghost marriage or met an adopted child who grew up in happiness knows that kinship is not biology, Malinowski's sentence - quoted in the motto - still rings true a hundred years later: "after all, kinship is a matter of flesh and blood, the result of sexual passion and maternal affection, of long intimate daily life, and of a host of personal intimate interest" (MALINOWSKI 1930).

Yes, kinship is about personal interests, as well as about economic relations, but the need for human reproduction is also an indispensable part of it. Therefore, I do not believe that the SPLA warlords are buying kinship with their herds of cattle; they are simply developing a patron - client relationship with their soldiers. Malinowski was right about kinship being more than just "bastard algebra", and that the complexity of the issue cannot be encompassed in tables and formulas. In South Sudan, especially at the DNPI, I observed the continued flexibility of the meaning of kinship. And this flexibility has constantly influenced people's view of kinship. Durka, the half Dinka, half Bari woman who repatriated from Switzerland and who had to look up her father to testify for her, developed a really good relationship with her father. One of my Kuku interviewees had to look for a far-removed paternal relative because her entire family lived in Uganda. This cousin, whom he would have never met under normal circumstances, traveled to Juba to help him, and in the three weeks they spent together, they became such good friends that my interviewee decided to move to his cousin's village instead of returning to Uganda.

But these flexible kinship situations cannot be understood without the normative basis of kinship, to which - like it or not - the road leads through "bastard algebra". These are the normative foundations which the police officers and applicants alike have referred to in their debates. Of course, these normative foundations are not closed sets expressed through formulas; oftentimes even two Dinka officials disagreed about a disputed issue. And these experienced, flexible kinship relations - such as the official naming system thus set up are themselves continually affecting the normative foundations treated as reference points. Anthropological research conducted in social spaces in which civilians confronting state powers must validate their family or ethnic identity - aside from citizenship agencies, I am thinking of border crossings, customs offices, child welfare agencies, and probate courts may have a lot to add to the topic of kinship, but it should not dismiss the kinship structures that are treated as norms by the participants in these debates.

\footnotetext{
${ }^{23}$ Pinaud talks exclusively of Nilotic army commanders and soldiers, although the SPLA/M is not limited to Nilotic soldiers; lots of Equatorians have also served in the army (RoLANDSEN 2005).

${ }^{24}$ Pinaud talks about torn family relationships, but I think use of the term "severed" would be more appropriate. The SPLA used a lot of child soldiers, during whose training a lot more time was spent on deriding their families than on their military training. For a long time, the training motto of the SPLA was the telling "Even my father, I will give him a bullet!" (ENSOR 2012; LeONARDi 2011).
} 


\section{REFERENCES CITED}

BOURDIEU, Pierre

1977 Outline of a Theory of Practice. Cambridge: Cambridge University Press.

CORMACK, Zoe

2014 The Making and Remaking of Gogrial. Landscape, History and Memory in South Sudan. Unpublished PhD dissertation, Durham University, Department of History.

DenG, Francis Mading

1972 The Dinka of the Sudan. Stanford: Stanford University Press.

ENSOR, Marisa O.

2012 Child Soldiers and Youth Citizens in South Sudan's Armed Conflict. Peace Review 24(3):276-283.

EvANS-PritchaRd, Evan Edward

1937 Witchcraft, Oracles and Magic among the Azande. Oxford: Oxford University Press.

1940 The Nuer. A Description of the Modes of Livelihood and Political Institutions of a Nilotic People. Oxford: Clarendon Press.

1951 Kinship and Marriage among the Nuer. Oxford: Clarendon Press.

1956 Nuer Religion. Oxford: Clarendon Press.

2011 The Divine Kingship of the Shilluk of the Nilotic Sudan. The Frazer Lecture, 1948, HAU: Journal of Ethnographic Theory 1(1):407-422.

EvENS, Terence M. S.

1984 Nuer Hierarchy. In GaLey, Jean-Claude (ed) Différences, Valeurs, Hiérarchie, [Differences, Values, Hierarchies], 319-334. Paris: Éditions de l'École des Hautes Études en Sciences Sociales.

FORTES, Meyer

1969 Kinship and the Social Order. London: Routledge and Kegan Paul.

ForTes, Meyer - Evans-Pritchard, Evan Edward

1940 African Political Systems. London: International African Institute.

FraZER, James

1913 The Dying God. (Part III of The Golden Bough.) London: Macmillan.

FREEMAN, Caren

2011 Making and Faking Kinship: Marriage and Labor Migration between China and South Korea. Ithaca: Cornell University Press.

GeERTZ, Clifford

1983 Common Sense as a Cultural System. In GeERTz, Clifford (ed) Local Knowledge 73-93. New York: Basic Books

GougH, Kathleen

1971 Nuer Kinship. A Re-Examination. In Biedelman, Thomas O. (ed) The Translation of Culture. Essays to E. E. Evans-Pritchard, 79-122. London: Tavistock Publications.

Graeber, David

2011 The Divine Kingship of the Shilla. On Violence, Utopia, and the Human Condition, or, Elements for an Archaeology of Sovereignty. HAU: Journal of Ethnographic Theory 1(1): 1-62. 
HoLÝ, Ladislav

1979a Nuer Politics. In HolÝ, Ladislav (ed) Segmentary Lineage Systems Reconsidered, 23-48. Belfast: Department of Social Anthropology, The Queen's University.

1979b The Segmentary Lineage Structure and Its Existential Status. In HOLÝ, Ladislav (ed) Segmentary Lineage Systems Reconsidered, 1-22. Belfast: Department of Social Anthropology, The Queen's University.

Howell, Paul Philip

1941 The Shilluk Settlement. In Sudan Notes and Records 24:47-67.

Hutchinson, Saron

1996 Nuer Dilemmas. Coping with Money, War, and the State. Berkeley: University of California Press.

JENNINGS, Richard

1989 Zande Logic and Western Logic. The British Journal for the Philosophy of Science 40(2):275-285.

JoHnson, Douglas H.

2003 The Root Causes of Sudan's Civil Wars. London: The International Africa Institution - Indiana University Press.

2010 When Boundaries Become Borders. The Impact of Boundary-Making in Southern Sudan's Frontier Zones. London: Rift Valley Institute.

KARP, Ivan - MAYNARD, Kent

1983 Reading the Nuer. Current Anthropology 24(4):481-503.

KUPER, Adam

1982 Lineage Theory. A Critical Retrospect. Annual Review of Anthropology 11:71-95.

LEONARDI, Cherry

2011 'Liberation' or Capture: Youth in between 'Hakuma' and 'Home' during Civil

War and its Aftermath in Southern Sudan. African Affairs 106(424):391-412.

LIENHARDT, Godfrey

1961 Divinity and Experience. The Religion of the Dinka. Oxford: Oxford University Press.

MALINOWSKI, Bronisław

1930 Kinship. MAN 30(1):19-29.

McKinnon, Susan

2000 Domestic Exceptions: Evans-Pritchard and the Creation of Nuer Patrilineality and Equality. Cultural Anthropology 15(1):35-83.

MARKó, Ferenc Dávid

2014 Gondolatok a rokonságról a dél-szudáni állampolgársági hivatalban. In SCHILlER, Katalin - TóTH-KIRzSA, Fruzsina (eds) Mwomboko. Festschrift for Mihály Sárkány’s 70 ${ }^{\text {th }}$ Birthday. MAKAT - ELTE Néprajzi Intézet, Budapest.

Peletz, Michael G.

1995 Kinship Studies in Late Twentieth-Century Anthropology. Annual Review of Anthropology 24:343-372.

PinAud, Clemence

2014 South Sudan. Civil War, Predation and the Making of a Military Aristocracy. African Affairs 113(451):192-211. 
RoLANDSEN, Øystein H.

2005 Guerrilla Government. Political Changes in the Southern Sudan during the 1990s. Uppsala: Nordic Africa Institute.

RosALDO, Renato

1986 From the Door of His Tent. The Fieldworker and the Inquisitor. In CLIFFORD, James-MARCUs, George E. (eds) Writing Culture, 77-97. Berkeley: University of California Press.

SAHLINs, Marshall

2013 What Kinship Is - And Is Not. Chicago: Chicago University Press.

SANKEY, Howard

2010 Witchcraft, Relativism and the Problem of the Criterion. Erkenntnis 72(1):1-16.

TRIPLETT, Tim

1994 Is There Anthropological Evidence that Logic is Culturally Relative? Remarks on Bloor, Jennings, and Evans-Pritchard. The British Journal for the Philosophy of Science 45(2):749-760.

VAN VleEt, Krista E.

2003 Adolescent Ambiguities and the Negotiation of Belonging in the Andes. Ethnology 42(4):349-363.

2008 Performing Kinship. Narrative, Gender, and the Intimacies of Power in the Andes. Austin: University of Texas Press.

Ferenc Dávid Markó is a PhD-applicant at the Department of Sociology and Social Anthropology, Central European University, Budapest and a researcher for Small Arms Survey, based in the Graduate Institute of International and Development Studies, Geneva. His PhD dissertation navigates around the nature of the state, through questioning widely accepted assumptions about state failure. Between 2013 and 2016 he conducted ethnographic fieldwork in South Sudan for 16 months, mostly inside the secretive realms of the new country's citizenship-bureaucracy. Email-address: marko_ferenc@phd.ceu.edu 